Imágenes en Urología

\title{
Presentación rara de ureterocele intravesical bilateral
}

\author{
Jorge Cabral Ribeiro, Américo Ribeiro dos Santos
}

Servicio de Urología. Hospital de São Marcos. Braga, Portugal

$\mathrm{V}$ arón, de 48 años, sin antecedentes patológicos de importancia. Acude al Servicio de Urgencia por dolor lumbar derecho asociado a hematuria macroscópica, interpretado como un cólico renal, confirmado por ecografía renal que documentó ureterohidronefrosis ligera y litiasis uréter proximal.

Observado en consulta de Urología meses después, resultó totalmente asintomático y sin referencia a expulsión de litiasis por lo que se realizó nueva ecografia renal y vesical que reveló litiasis en el uréter terminal derecho con la hipótesis de existir un pólipo vesical junto al meato ureteral (Fig. 1).

La uretrocistoscopia que documentó un ureterocele intravesical bilateral (Fig. 2) condicionó una evaluación complementaria. La urografía intravenosa reveló normalidad morfofuncional renal bilateral con ureterocele intravesical bilateral e imagen de substracción ureter distal derecho (imagen no radiopaca - Fig. 3 y 4); la cis- tografía retrógrada y permiccional no reveló reflujo y el renograma no documentó obstrucción urinaria. El TAC pélvico confirmó la litiasis ureteral distal (Fig. 5).

La conclusión fue que se trataba de un ureterocele bilateral intravesical no obstructivo y sin reflujo en unidades ureterales simples que se complicó con cólico sin eliminación del cálculo.

Se procedió a la incisión del ureterocele derecho, extracción y fragmentación endoscópica del cálculo (Fig. 6).

\section{Agradecimientos}

Los autores agradecen la colaboración de Carlos Calaza

Correspondencia autor: Jorge Cabral Ribeiro Servicio de Urología. Hospital de São Marcos Apartado 2242 - 4701-965 Braga Portugal E-mail autor: jcabral@hsmbraga.min-saude.pt Información artículo: Imágenes en Urología Trabajo recibido: octubre 2007

Trabajo aceptado: noviembre 2007

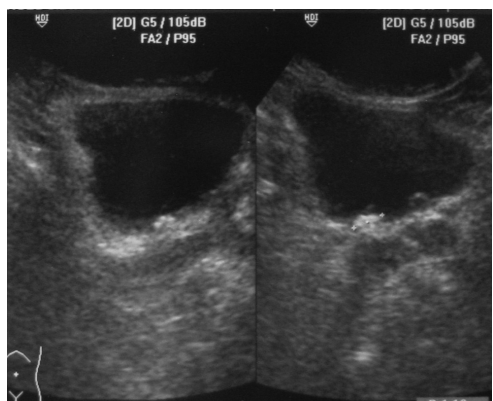

FIGURA 1

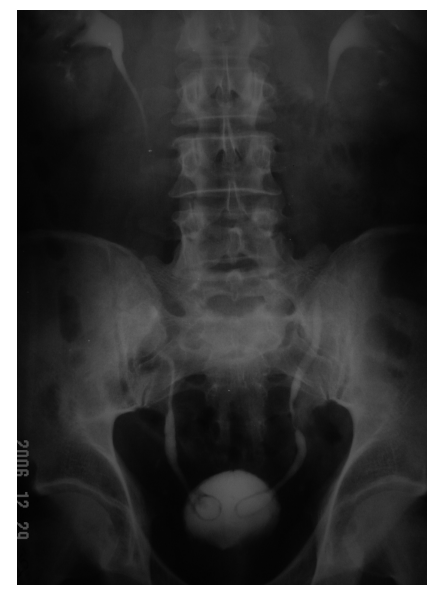

FIGURA 4

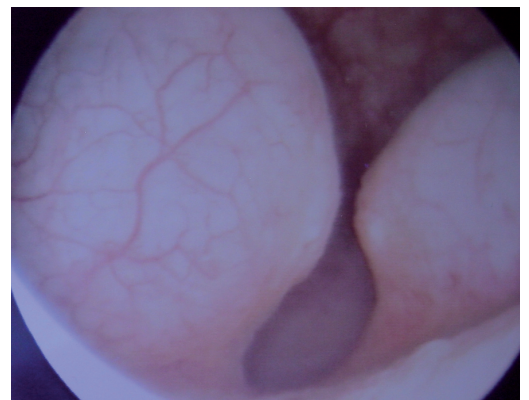

FIGURA 2

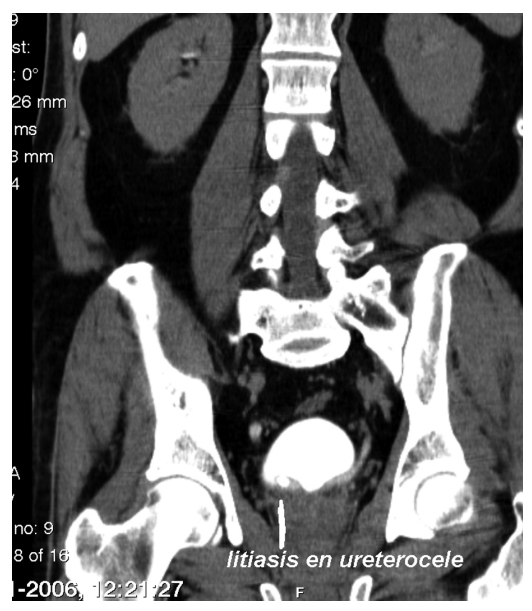

FIGURA 5

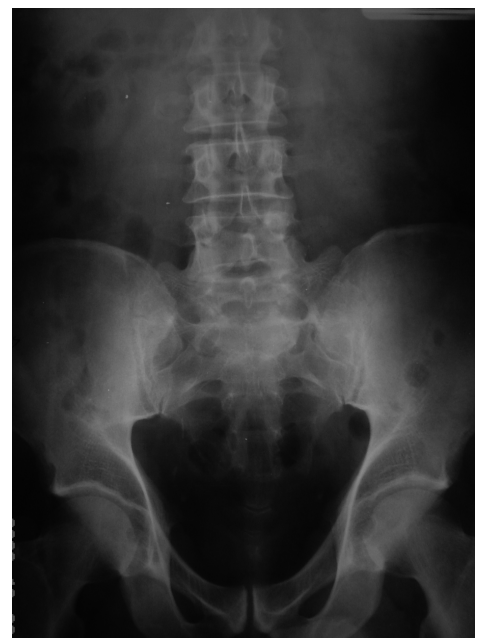

FIGURA 3

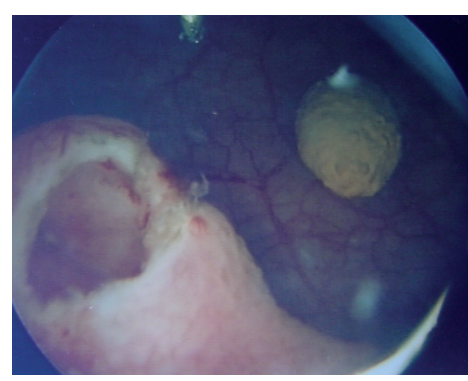

FIGURA 6 